\title{
ONE SAYS THE THINGS WHICH ONE FEELS THE NEED TO SAY, AND WHICH THE OTHER WILL NOT UNDERSTAND: ${ }^{1}$ SLOVAK PENSION CASES BEFORE THE CJEU AND CZECH COURTS
}

\author{
Agata B Capik* and Martin Petschko**2
}

\begin{abstract}
In a spectacular decision, in 2012 the Czech Constitutional Court declared the Landtova judgment of the CJEU ultra vires and therefore inapplicable on the territory of that Member State. The CJEU's judgment was rendered following a request for a preliminary ruling by the Czech Supreme Administrative Court. The real and underlying conflict, however, was of an internal nature and took place between two of the highest courts of the Czech Republic well into 2013, making it an illustrative example of how the mechanisms of judicial dialogue actually work in practice. This contribution first looks at both the horizontal and vertical aspects of the so-called Slovak Pension Cases. It further assesses them from the perspective of judicial dialogue in its procedural and substantial features, while finally discerning possible consequences that the ultra vires decision of the Czech Constitutional Court might bring about.
\end{abstract}

\section{Introduction}

One cannot but describe the recent interactions between some of the Czech judiciary's most prominent courts and the Court of Justice of the European Union (CJEU) with respect to the so-called Slovak Pension Cases as a saga. ${ }^{3}$ All of the necessary elements of a drama are present: a prominent divorce, desire for money, and finally a struggle for authority and influence. Moreover, it includes a great deal of suspense as well as surprising twists and turns. However, one might argue whether it should qualify as a drama or rather as a farce.

\footnotetext{
1 The title of this contribution is inspired by a quote by Marcel Proust from In Search of Lost Time.

* Agata B Capik is a former post-doctoral researcher at the Centre for European Law at the University of Luxembourg, and is currently head of the 'Law of Europe' research project.

** Martin Petschko is a research associate at the University of Luxembourg.

2 The authors wish to thank Professor Michal Bobek, Dr Maja Brkan and Dr Adam Łazowski for their valuable comments on earlier drafts of this paper. The usual disclaimer applies.

3 For the purposes of this contribution, the term Slovak Pension Cases is not limited to the underlying cases brought before the Czech courts, but also includes the preliminary references lodged with the CJEU.
} 
The Slovak Pension Cases led the Constitutional Court of the Czech Republic (Ústauni soud České republiky (CCC)) to declare ${ }^{4}$ the CJEU's 2011 Landtová judgment ${ }^{5}$ ultra vires. The CCC's remarkable determination was swiftly put into question by its Brno neighbour, the Supreme Administrative Court of the Czech Republic (Nejvyšši správni soud České republiky (SAC)). The latter initiated further preliminary ruling proceedings before the CJEU ${ }^{6}$ based on a set of facts similar to those underlying Landtová. The stage was thus set for a brilliant finale and the audience held their breath, waiting for the CJEU's decision. However, before a judgment could be rendered, the SAC reluctantly withdrew its request, after the case had been settled by means of an out-of-court settlement at the national level. ${ }^{7}$

The Slovak Pension Cases saga represents a longstanding jurisprudential debate between two of the highest courts in the Czech Republic, making it an illustrative example of how the mechanisms of judicial dialogue actually work in practice with regard to form and content. Moreover, it raises certain interesting procedural questions at the European Union level, particularly regarding the uniform application of European Union law. Thus, for a number of reasons, the proceedings in the Slovak Pension Cases can be characterised as quite spectacular. Whether this same attribute can be applied to the consequences that such proceedings will ultimately produce - and the implications thereof on the EU legal order as a whole - remains, for the time being, significantly more difficult to discern.

This contribution will begin by describing the Slovak Pension Cases, including their horizontal aspect, ie first and foremost the interaction between the CCC and SAC, as well as their vertical aspect, which developed between these courts and the CJEU. As a second step, it will aim at assessing these developments from the perspective of judicial dialogue. This second part will be further subdivided into a section on the material and procedural aspects of the cases at hand, and also a section on the ultra vires review, which will suggest possible conclusions to be drawn from these proceedings.

\footnotetext{
4 Czech Constitutional Court, Slovak Pensions XVIII, judgment of 31 January 2012, P1. ÚS 5/12. An English language translation is available on the official CCC website: <http:// www.usoud.cz/en/decisions /?tx_ttnews[tt_news]=37\&cHash=911a315c9c22ea1989d19a3 a848724e2> accessed 27 December 2013.

5 Case C-399/09 Marie Landtová v Česká správa socialního zabezpečení [2011] ECR I-5573.

6 Application in Case C-253/12 JS v Česká správa sociálního zabezpečení, reference for a preliminary ruling lodged on 24 May 2012 [2012] OJ EU C273/2.

7 Order of the Court in Case C-253/12 (n 6) of 27 March 2013 that the case be removed from the register [2013] OJ EU C225/57.
} 


\section{Facts and proceedings}

An entire discussion of all the ins and outs of the various proceedings in the Slovak Pension Cases is far beyond the scope of this contribution. ${ }^{8}$ In a nutshell, however, the essential, underlying dispute arose in the wake of the dissolution of the Czech and Slovak Federal Republic, then known as Czechoslovakia. ${ }^{9}$ The two resulting countries, the Czech Republic and the Slovak Republic (Slovakia) concluded a bilateral treaty ${ }^{10}$ governing the responsibility and calculation of individual pension rights that had been acquired under the Czechoslovakian regime (the Bilateral Treaty). ${ }^{11}$ It established that each state would take responsibility for individual pension rights based on the employer's headquarters on 31 December 1992. After that date, the respective legislation of each of the two States would apply to determine pension rights acquired by individual employees. Accordingly, pension rights acquired by an individual working for an employer having its headquarters in Slovakia would be governed by Slovakia's legal regime and administered by its authorities, ${ }^{12}$ and vice versa.

Over time, however, due to differences in the economic development occurring in the Czech Republic and Slovakia, pension benefits developed at a far slower rate in Slovakia, ${ }^{13}$ resulting in Slovakian pension payments that were substantially lower than their Czech equivalent. ${ }^{14}$

\footnotetext{
8 For a concise description of the underlying facts and procedural history, cf Pavel Molek, 'The Court that Roared: The Czech Constitutional Court Declaring War of Independence against the ECJ' (2012) 6 ELR 162-169.

9 Based on Constitutional Act Number 542/1992 Coll, adopted by the former Federal Assembly on 25 November 1992, the Federation's dissolution date was established as 31 December 1992. Subsequently, as of 1 January 1993, both new States took over the authority entrusted previously by constitutional and other acts to the former federation.

10 Smlouva mezi Českou republikou a Slovenskou republikou o sociálním zabezpečení (Agreement between the Czech Republic and Slovak Republic on Social Security), signed on 29 October 1992. A Czech language version is available at <http://www.mpsv.cz/files/ clanky/1542/smlouva_slovensko.pdf> accessed 27 December 2013.

11 In Czechoslovakia, the pension system used to be within the competence of the federation, while the republics fulfilled only certain functions of a rather administrative nature in such matters. Cf Robert Zbiral, 'Czech Constitutional Court, Judgment of 31 January 2012, Pl. ÚS 5/12, A Legal Revolution or Negligible Episode? Court of Justice Decision proclaimed Ultra Vires' (2012) 49 CML Rev 1-18, 2.

12 Art 20(1) of the Bilateral Treaty provides that: 'periods of insurance completed before the date of dissolution of the Czech and Slovak Federal Republic shall be considered to be periods of insurance completed in the contracting State on whose territory the employer of the person concerned had its headquarters either on the day of the dissolution, or on the last day before that date.' Quoted from Landtová (n 5).

13 This is no longer the case, due to the social security reforms undertaken by the Slovak government. Cf Molek (n 8) 167.

14 Jan Komárek, 'Playing with Matches: The Czech Constitutional Court Declares a Judgment of the Court of Justice Ultra Vires: Judgment of 31 January 2012, Pl. US 5/12, Slovak Pensions XVIr, (2012) 8 European Constitutional LR 323-337; Zbíral (n 11), 2.
} 
This disparity engendered considerable discontent among individuals who, although living in the Czech Republic, had worked for employers with headquarters in Slovakia, as those individuals received the lower Slovakian pensions rather than the higher Czech ones. Consequently, employees who had done essentially the same work, but in different places, ended up receiving different pension payments. To rectify this perceived inequity, the Czech Social Security Administration (CSA) ${ }^{15}$ sometimes chose to provide an ex gratia compensatory supplement that was intended to alleviate hardship, a practice which complied with the Bilateral Treaty. However, a number of applications for such a supplement were denied on the basis that the underlying pension was slightly too high and did not result in the pensioner suffering from hardship, even though the pensions were still below the Czech average. Such decisions were unsuccessfully challenged before the relevant $\mathrm{Czech}$ administrative courts, including the SAC. These claims, however, met with far greater success before the CCC. ${ }^{16}$ Unlike the SAC, the CCC held that a decision to deny the supplement to some while granting it to others who were similarlysituated was incompatible with the right to social security in old age and the principle of equality. ${ }^{17}$

The SAC, on the other hand, remained unconvinced by the CCC's reasoning. ${ }^{18}$ Consequently, it raised two challenges in the next case it heard subsequent to the CCC decision. Firstly, as it determined that Regulation 1408/71 (the Regulation) applied, and Article 12 thereof prohibited the taking into account of pension periods more than once, the SAC questioned whether the compensatory supplement was incompatible with the Regulation, as it amounted to taking an individual's pension periods into account more than was permitted by the Regulation. Secondly, the SAC questioned whether it was in line with EU law to restrict the compen-

\footnotetext{
15 The CSA is the financial organisation of the Czech public administration, falling under the Czech Ministry of Labour and Social Affairs. Cf <http://www.cssz.cz/en/about-cssa/> accessed 27 December 2013.

16 See, inter alia, Czech Constitutional Court, Slovak Pensions judgment of 20 March 2007, Pl. ÚS 4/06, as well as the judgment of 12 August 2010, III. ÚS 1012/10.

17 The Czech Constitutional Court had already decided, in its constitutionally conforming interpretation judgment of 25 January 2005, III. ÚS 252/04, that Article 20(1) of the Agreement must be applied in such a way that 'where a national of the Czech Republic satisfies the statutory conditions for entitlement to a pension, the amount of which as set by national law (of the Czech Republic) is greater than that laid down by the Agreement, it is for the Czech Social Security Administration to ensure that the retirement pension is of an amount equivalent to the higher entitlement set by national legislation and to order that the amount of the retirement pension paid by the other contracting party be supplemented, taking account of the retirement pension paid by the other contracting party under the Agreement in order to avoid double payment of two retirement pensions of the same kind, granted on the same grounds by two separate social security institutions'. See also Slovak Pensions (n 16).

18 For details on the internal dialogue between the SAC and CCC, see, inter alia, Molek (n 8) 163.
} 
satory supplements exclusively to Czech citizens residing in the Czech Republic. Accordingly, the SAC referred the case to the CJEU, ${ }^{19}$ seeking a resolution of these two questions. ${ }^{20}$

Eventually, the CJEU answered both questions in the negative. With respect to the first one, it found that:

the provisions of point 6 of Annex III(A) to Regulation No 1408/71, read in conjunction with Article $7(2)$ (c) thereof, do not preclude a national rule, such as that at issue in the main proceedings, which provides for payment of a supplement to old age benefit where the amount of such benefit, awarded under Article 20 of the Agreement, is lower than that which would have been received if the retirement pension had been calculated in accordance with the legal rules of the Czech Republic. ${ }^{21}$

Thus, according to the CJEU, providing compensatory supplements was compatible with the Regulation. However, the answer to the second question had an entirely different impact on such compensatory supplements:

[T] $1408 / 71$ preclude a national rule, such as that at issue in the main proceedings, which allows payment of a supplement to old age benefit solely to Czech nationals residing in the territory of the Czech Republic, but it does not necessarily follow, under EU law, that an individual who satisfies those two requirements should be deprived of such a payment. ${ }^{22}$

Therefore, while the CJEU found compensatory supplements to be compatible with EU law, it insisted on a non-discriminatory application of the rule, thereby leaving the CSA with considerable room to manoeuvre. In essence, it could decide to give the compensatory supplement to everyone or no one. ${ }^{23}$

Once it had received the CJEU's judgment, the SAC issued its decision in the case. ${ }^{24}$ It held that firstly the CCC's jurisprudence was in-

\footnotetext{
19 Landtová (n 5).

20 This reference for a preliminary ruling concerned the interpretation of Article 12 EC and Articles 3(1), 7(2)(c), 10 and 46 of Council Regulation (EEC) 1408/71 of 14 June 1971 on the application of social security schemes to employed persons, to self-employed persons and to members of their families moving within the Community, as amended and updated by Council Regulation (EC) 118/97 of 2 December 1996 [1997] OJ EC L28/ 1 and as amended by Regulation (EC) 629/2006 of the European Parliament and of the Council of 5 April 2006 [2006] OJ EU L114/1, and point 6 of Annex III(A) to Regulation No 1408/71.

21 Landtová (n 5) para 40.

22 Landtová (n 5) para 54.

23 Landtová (n 5) para 41-49.

24 Czech Supreme Administrative Court, decision of 31 August 2011, 6 Ads 52/2009-88.
} 
consistent with the CJEU's interpretation of EU law and secondly that, even though the SAC respected both, faced with these two irreconcilable jurisprudential approaches, it would follow the CJEU. Only exceptionally would it give precedence to the CCC's jurisprudence in cases where the latter invoked the hard core of the constitution's primacy vis-à-vis EU law. The latter, therefore, upheld the CSA's decision to refuse to accord the compensatory supplement to the applicant. Consequently, the SAC arguably won the 'war' between the Czech Courts, although its victory was fleeting. ${ }^{25}$

Subsequently, in a move that was both unprecedented and that took most observers by surprise, the CCC launched a counter-attack. When the next case similar to Landtová came before it, the CCC declared the latter to be ultra vires, so that it had no force or effect in the Czech Republic. The CCC was clearly disgruntled by the CJEU's ruling, as it had rejected the former's reasoning and must have appeared to be undermining the CCC's authority over the SAC. ${ }^{26}$ The CCC therefore decided to hit back and in administering its response, it reasoned that in the first place the Regulation was not even applicable, since the case at hand did not contain any cross-border element, as the underlying facts took place entirely within Czechoslovakia. The Czech Republic was, therefore, in a position to apply only the Bilateral Treaty and not EU law, and the compensatory supplements were legal pursuant to the former. Secondly, the Bilateral Treaty could be applied independently of the Regulation because, even if the Regulation was applicable, the Bilateral Treaty was specifically mentioned in the Regulation's Annex III, which meant that the Bilateral Treaty remained independently applicable. In the CCC's view, all treaties mentioned therein could and should be applied independently of the Regulation, and even more importantly, also independently of EU law in general. Thus, according to the CCC's reasoning, there was no requirement to apply the rules contained in the Bilateral Treaty in a nondiscriminatory manner. Rather, because the EU's general prohibition of discrimination was not applicable to the Bilateral Treaty, it was perfectly acceptable to limit compensatory supplements to only Czech nationals resident in the Czech Republic. Finally, the CCC held, using harsh and highly critical language, that the CJEU had transgressed the powers transferred to it by the Member States and consequently, the Landtová decision was not applicable in the Czech Republic. ${ }^{27}$

\footnotetext{
25 For an overview of the CCC and SAC decisions on Slovak Pensions see, inter alia, Molek (n 8) 163-165, with further references.

26 Czech Constitutional Court, Slovak Pension XVII judgment of 31 January 2012, Pl. ÚS $5 / 12$, concerning a Czech national who had worked for many years in Bratislava before the dissolution of Czechoslovakia.

27 However, the material singularity of such a statement is not the only remarkable aspect of the CCC's judgment. In addition to those of a more material nature, there is the
} 
It is obvious that the $\mathrm{CCC}$ intended to bring this thorny saga to a dramatic, yet-definitive, close. However, it underestimated the SAC's resolve to have the final word. Although the SAC had, throughout its early jurisprudence, suggested its willingness to follow the CCC's decisions ${ }^{28}$ to the extent it could legitimately do so in accordance with applicable EU law, it subsequently decided to challenge the CCC's authority. When another similar case came before it, the SAC quickly seized the opportunity to initiate yet another request for a preliminary ruling to the CJEU, essentially looking to the CJEU to help it resolve the Czech courts' power struggle. ${ }^{29}$ There was one question which could provoke an answer with far-reaching implications, specifically:

Does European Union law prevent the national court, which is the highest court in the State in the field of administrative law and against whose decision there is no right of appeal, from being, in accordance with national law, bound by the legal assessment of the Constitutional Court of the Czech Republic where that assessment seems not to be in accordance with Union law as interpreted by the Court of Justice of the European Union (emphasis added)?

However, in February 2013 the SAC withdrew this request for a preliminary ruling, as the underlying dispute had been solved by means of an out-of-court settlement.

\section{Reflections on judicial dialogue}

\subsection{Material and procedural aspects}

The pointillist picture provided above has already made clear that the Slovak Pension Cases are deserving of attention in many respects. The following sections assess Landtová from the theoretical standpoint of judicial dialogue. We will evaluate those aspects of the saga that provide an insight into judicial dialogue in action, thereby contributing to a better understanding of its strengths and shortcomings.

The legal phenomenon of judicial dialogue, together with the preliminary reference procedure as its pivotal tool and the main communication channel between national courts and the CJEU, constitutes a vital feature of the European legal order due to the particular character of the

judgment's phrasing that can hardly be qualified as other than forceful or, during certain passages, even aggressive. At least this is true for the English language translation available on the CCC's official website.

28 Molek (n 8) 163.

29 Case C-253/12 (n 6). The subsequent removal from the register was performed by the Order of 27 March 2013 (n 7). 
CJEU's jurisdiction. ${ }^{30}$ This has been extensively discussed in both institutional $^{31}$ and academic ${ }^{32}$ forums. Nevertheless, it was only in Kempter ${ }^{33}$ that the CJEU, following the Opinion of Advocate General Bot, ${ }^{34}$ stated expressis verbis that 'the preliminary ruling is based on a dialogue between one court and another', ${ }^{35}$ thus making for the very first time an explicit reference to dialogue between the CJEU and national courts. ${ }^{36}$

Against this backdrop, a selection of procedural and material questions raised by the Slovak Pension Cases will now be discussed, followed by an observation with regard to the ultra vires review.

\footnotetext{
30 Francis Geoffrey Jacobs, 'Judicial Dialogue and the Cross-Fertilization of Legal Systems: The European Court of Justice', (2003) 38 Texas International Law Journal 547-557, 548. For the importance of a harmonious working relationship between the CJEU and national courts see, inter alia, Case 16/65 Schwarze/Einfuhr- und Vorratstelle für Getreide und Futtermittel [1965] ECR 877; Case 107/76 Hoffmann-La Roche AG v Centrafarm Vertriebsgesellschaft Pharmazeutischer Erzeugnisse mbH [1977] ECR 957; Case C-99/00 Criminal proceedings against Kenny Roland Lyckeskog [2002] ECR I-4839.

31 See, inter alia, 'Report on the Future of the Judicial System of the European Union' (1999), followed by Working Party for the European Commission (Ole Due), 'Report of the Working Party on the Future of the European Communities' Court System' (Brussels 2000) available at <http://ec.europa.eu/dgs/legal_service/pdf/due_en.pdf> accessed 27 December 2013; Association of the Councils of State and Supreme Administrative Jurisdictions of the European Union, 'Report of the Working Group on the Preliminary Ruling Procedure (The Hague 2007), available at <http://www.juradmin.eu/en/newsletter/pdf/Hr_20-En. pdf> accessed 27 December 2013; Committee on Legal Affairs of the European Parliament (Diana Wallis), 'Report on the Role of the National Judge in the European Judicial System' (A6-0224/2008), which led to the European Parliament resolution of 9 July 2008 on the role of the national judge in the European judicial system (2007/2027(INI)). All documents leading to the Resolution and the Resolution itself are available at <http://www.europarl. europa.eu / sides / getDoc.do? type=REPORT\&reference=A6-2008-0224\&language=EN > accessed 27 December 2013.

32 Going back to at least Anne-Marie Slaughter, Alec Stone Sweet and JHH Weiler (eds), The European Court of Justice and National Courts - Doctrine and Jurisprudence: Legal Changes in its Social Context (Hart Publishing 1998). To name the most recent: Arthur Dyevre, 'Judicial Non-Compliance in a Non-Hierarchical Legal Order: Isolated Accident or Omen of Judicial Armageddon?’ (15 June 2012). Available at SSRN: <http://ssrn.com/ abstract=2084639 > accessed 27 December 2013; Emmanuelle Bribosia, Laurent Scheeck and Amaya Úbeda de Torres, L'Europe des Cours. Loyautés et résistances (Emile Bruylant 2010); Monica Claes, Maartje de Visser, Patricia Popelier and Catherine Van de Heyning (eds), Constitutional Conversations in Europe (Intersentia 2012); Filippo Fontanelli, Giuseppe Martinico and Paolo Carrozza, Shaping Rule of Law through Dialogue: International and Supranational Experiences (Europa Law Publishing 2010); François Lichère, Laurence Potvin-Solis and Arnaud Raynouard, Le dialogue entre les juges européens et nationaux: incantation ou réalité ? (Emile Bruylant 2004).

33 Case C-2/06 Willy Kempter KG v Hauptzollamt Hamburg-Jonas [2008] ECR I-411.

34 Kempter (n 33) Opinion of AG Bot, para 101.

35 Kempter (n 33) para 42.

36 Cf Xavier Groussot, 'Spirit, Are You There? Reinforced Judicial Dialogue and the Preliminary Ruling Procedure', Eric Stein Working Papers (2008) 4, available at <http://www. ericsteinpapers.cz/info/papers/2008-4> accessed 11 November 2013; Diana-Urania Galetta, Procedural Autonomy of EU Member States: Paradise Lost? A Study on the 'Functionalized Procedural Competence' of EU Member States (Springer 2010) 58.
} 
As indicated above, the proceedings in themselves were relatively straightforward, inasmuch as they displayed many features typical of such preliminary references that also involve an internal power struggle between national courts. These can schematically be described as follows: National Court A disapproves of a specific legal approach its superior Court B applies in its jurisprudence. In an effort to undermine Court B's authority, Court A lodges a preliminary reference with the CJEU. Eventually, the CJEU reaffirms Court A's position, thereby allowing it to legitimately oppose Court B's approach. ${ }^{37}$ This effect may be labelled as 'authority corroding'.

When assessing the Slovak Pension Cases from the wider perspective of judicial dialogue, the phenomenon described above elaborately shows that in practice such dialogue is far from always being entertained with mutual respect and understanding. ${ }^{38}$ Less noble factors and motives, such as the struggle for judicial power, play an equally important role. In this respect, the Slovak Pension Cases constitute a compelling example of the challenge that arises in constitutional courts via the use of preliminary reference procedures by courts of lower instance. One may discern two distinct categories of this phenomenon, which incidentally is already predetermined by primary EU law $^{39}$ and the specific interpretation this procedure receives from the CJEU. On the one hand, national courts have no restrictions regarding their interpretation of material law and on the other there are no procedural restrictions regarding the authority of their constitutional courts. ${ }^{40}$

With regard to the first category, the corrosion of 'material authority', the Slovak Pension Cases are instructive, as they involve a struggle for the correct material interpretation of law between two national courts. Which of the two courts, however, had the better legal arguments with regard to the interpretation of the Regulation? Was the CCC right in its approach? An assessment of this question will show that the CCC missed important points and that the conclusions it drew can hardly be upheld.

Firstly, claiming that Regulation $1408 / 71$ was not applicable due to the lack of a cross-border element appears unsustainable. The provisions of Article 2 define the preconditions that have to be met in order to establish its applicability. The mere fact that a person is subject to the legi-

\footnotetext{
37 For a more detailed assessment of this phenomenon, see M Bobek, The Impact of the European Mandate of Ordinary Courts on the Position of Constitutional Courts', in Claes, de Visser, Popelier and Van de Heyning (n 32) 287-308.

38 Elinia Paunio, 'Conflict, Power and Understanding: Judicial Dialogue between the ECJ and National Courts', (2010) 7 No Foundations 5-24.

39 Art 267 TFEU, Art 23 of the Statute of the Court of Justice, Arts 93-118 of the Rules of Procedure before the Court of Justice of the European Union.

40 Further distinctions can be found in Bobek (n 37) 292.
} 
slation of one or two Member States suffices in this respect. As the applicants in the cases at hand were undoubtedly subject to the legislation of a Member State, there is no room for doubt: Regulation 1408/71 applies.

Secondly, the conclusions drawn by the CCC from the fact that the Bilateral Treaty appears in Annex III of Regulation 1408/71 are erroneous. The Bilateral Treaty is incorporated in Part A of the Annex, which mentions all social security conventions that are still applicable regardless of the Regulation's entry into force. However, the conventions of Part A have to be applied in a non-discriminatory manner, as the principles of EU law clearly apply (as opposed to those of Part B, which may include discriminatory measures). The reason for such an extraordinary slip on the part of the CCC has given rise to a certain measure of speculation. ${ }^{41}$ What is clear is that the two main material pillars upon which the CCC founded its decision are extremely difficult to uphold, not to mention that the arguments are simply incorrect.

As already indicated above, the Landtová saga further merits attention with regard to the second category, namely the circumvention of procedural authority. According to the CJEU's case law, on the one hand national courts are entitled to ignore procedural rules requiring them to first refer a matter to their constitutional court before making a reference to Luxembourg. ${ }^{42}$ On the other hand, superior courts do not enjoy the competence to prevent national courts of a lower instance from lodging preliminary references in an effort to affirm their authority. ${ }^{43}$ That the Landtová saga touches upon many of these neuralgic questions and is therefore a particularly representative case in this respect has already become clear.

In the context described above, one move of the CCC appears particularly odd. After having lodged its preliminary reference in Landtová, the SAC suspended a couple of similar cases. One of the parties concerned appealed against this decision to the CCC and the latter annulled the underlying decision of the SAC, essentially arguing that a reference was not necessary due to the unequivocal case law of the $\mathrm{CCC}$, and that the SAC was bound by it. ${ }^{44}$ This clearly appears to be in conflict with the jurisprudence of the CJEU as mentioned above. ${ }^{45}$

The particular irony of Landtová, however, is that in this specific case the preliminary reference procedure might have actually strengthe-

\footnotetext{
41 Zbíral (n 11) 10.

42 Cf Case C-348/89 Mecanarte-Metalúrgica da Lagoa Ld ${ }^{a} v$ Chefe do Serviço da Conferência Final da Alfândega do Porto [1991] ECR I-3277.

43 Case C-210/06 Cartesio Oktató és Szolgáltató bt [2008] ECR I-9641 and Case C-173/09 Georgi Ivanov Elchinov v Natsionalna zdravnoosiguritelna kasa [2010] ECR I-8889.

44 Zbiral (n 11) 11. This reaction by the CCC demonstrates how seriously it took the challenge to its authority.

45 Elchinov and Cartesio (n 43).
} 
ned the CCC's position and saved it a considerable amount of trouble. Had the CCC only launched a preliminary reference itself, the CJEU's judgment ${ }^{46}$ would have provided the necessary flexibility for the CCC to further apply its approach and grant the compensatory supplement to all Czech citizens. The only concession the CCC would have had to make is that non-citizens would also have had to be entitled to it.

After having had a look at the authority corroding effect the preliminary ruling procedure can display, the following analysis aims at providing an answer to the question why the CCC actually reacted in such an uncompromising way vis-à-vis the SAC as well as the CJEU - a task that is not easy to accomplish. The CCC's jurisprudence up to this point had provided little indication to this effect. ${ }^{47}$ On the contrary, the previous relationship between the $\mathrm{CCC}$ and the SAC was one characterised by respect and as being 'fruitful'. ${ }^{48}$ Whenever the CCC was called upon to decide in cases pertaining to European integration and its impact upon the Czech legal system, it would appear fair to describe its stance as not particularly critical, or in other words as pro-European. ${ }^{49}$ From the outside point of view of a scholarly observer, its motivation seems in fact to stem from sources other than strictly legal ones. ${ }^{50}$

To begin with a very broad and abstract remark, there are factors that corroborate the presumption that the CCC was in part driven by a motivation that goes back to the roots of the case. The particular attachment the CCC displayed with regard to the Slovak Pension Cases might be explained by its resolve to spare Czech citizens any harm potentially attributable to the dissolution of Czechoslovakia, as this had been predominantly engineered by the political elite of the country and was never subject to a referendum. ${ }^{51}$

Furthermore, the particular way the procedure before the CJEU developed was certainly not to the liking of the CCC. For example, the fact

\footnotetext{
46 Under the assumption that the CJEU would have come to the same conclusions in such a judgment, which appears perfectly justifiable.

47 Czech Constitutional Court, Sugar Quotas III judgment of 8 March 2006, Pl. ÚS 50/04; European Arrest Warrant judgment of 3 May 2006, Pl. ÚS 66/04; Lisbon Treaty I judgment of 26 November 2008, Pl. ÚS 19/08; Non-Applicability of Contested Provision judgment of 2 December 2008, PL. ÚS 12/08; Lisbon Treaty II judgment of 3 November 2009, PL. ÚS 29/09. An English language translation of all the judgments is available at <http://www. concourt.cz/view/726> accessed 27 December 2013.

48 Molek (n 8) 162.

49 Jan M Passer, 'The Relation between EU Fundamental Rights and those Recognized in the Constitutions of the Member States: Competition or Complementarity?' Speech delivered at the Conference on Protection of Fundamental Rights in the EU: Future Challenges, Section 2 - How to Manage the Pluralism of Sources of Fundamental Rights in the EU, Luxembourg 22 October 2012. This assessment holds true even though the CCC has actually never itself lodged a preliminary reference procedure.

50 This interpretation is confirmed by Molek (n 8) 168 with further references.

51 Molek (n 8) 168.
} 
that the Czech Government, as an intervenient in the proceedings before the CJEU, had claimed that the CCC's jurisprudence in this respect was contrary to EU law is fairly unusual. ${ }^{52}$ The fact that its own government had 'stabbed it in the back' seems to have contributed to a general feeling of distrust within the CCC. The CCC was certainly not about to accept such an accusation, and considered the case to have not been properly defended before the CJEU. The CCC therefore saw only one remaining way to inform the CJEU of the positions it had taken. Imaginative minds may even perceive this step as the failed attempt of a judicial dialogue: the CCC simply drafted a letter stating its case. Unsurprisingly, however, the CJEU's Registry returned the letter, as the CCC was in no way associated with the proceedings, stating that 'according to what is established practice, the members of the CJEU do not exchange correspondence with third parties concerning the cases submitted to the CJEU'. ${ }^{53}$ The CCC's pride was obviously hurt, as it took up this point in its judgment by stating that:

the ECJ regularly makes use of the institution of amici curiae in proceedings on preliminary questions, especially in relation to the European Commission. In a situation where the ECJ was aware that the Czech Republic, as a party to the proceeding, in whose name the government acted, expressed in its statement a negative position on the legal opinion of the Constitutional Court, which was the subject matter for evaluation, the ECJ statement that the Constitutional Court was a 'third party' in the case at hand cannot be seen otherwise than as abandoning the principle audiatur et altera pars.

Given that the rules that are applicable to proceedings before the $\mathrm{CJEU}^{54}$ do not provide for such contact with national courts in a situation as the one in Landtová, it is difficult to see in what way this would amount to a violation of a procedural principle. Given that the CCC further qualified the CJEU's behaviour as amounting to 'deficiencies concerning the safeguards of a fair trial in the proceeding before the ECJ in Case C-399/09',55 it merits particular attention that, in accordance with the normative approach of public international law - borrowed subsequently by EU law ${ }^{56}$ - the right to a fair trial is a norm designed to protect individuals from the unlawful and arbitrary curtailment or deprivation of fundamental rights and freedoms. It thus appears fairly inappropriate that

\footnotetext{
52 For further details in this respect, cf Zbiral (n 11) 4.

53 Czech Constitutional Court (n 26).

54 Especially Arts 93-118 Rules of Procedure of the Court of Justice [2012] OJ EU L 265/1.

55 Czech Constitutional Court, judgment of 31 January 2012, PL. US 05/12.

56 The right to a fair trial and defence are set out in Articles 47 and 48 of the EU Charter of Fundamental Rights and in Article 6 of the European Convention on Human Rights, the latter being mentioned expressis verbis in the provisions of Article 6 TEU.
} 
the CCC, which in fact is the guardian of rights in the Czech Republic, ${ }^{57}$ argues as though courts equally enjoyed such rights.

Against the backdrop of even the Constitutional Court of a Member State being manifestly unaware of the specific purpose and functions of amici curiae, ${ }^{58}$ it is justified to enquire as to how solid the national courts' knowledge regarding the features of the preliminary ruling procedure actually is. Incidentally, this question is in no way a new one, particularly since the enlargements of 2004 and $2007 .{ }^{59}$ Familiarity with the procedural requirements before the CJEU has already been a subject of discussion at different forums ${ }^{60}$ for many years, ${ }^{61}$ and an apparent majority of judges (54\%) regarded themselves as familiar with the procedure. ${ }^{62}$ At that time, only $13 \%$ of judges in the Czech Republic considered themselves 'unfamiliar' with it. ${ }^{63}$ These numbers are elaborately exemplified by the Slovak Pension Cases.

It has become clear that the CCC's hurt pride played a considerable role in its uncompromising reaction. Unfortunately, the triggering moment for this may very well have had to do with a certain lack of familiarity regarding the rules of procedure applicable before the CJEU. The $\mathrm{CCC}$ is by no means the only national court that is faced with deficiencies of this kind.

\footnotetext{
57 Krcmar $v$ the Czech Republic App no 35376/97 (ECtHR, 3 March 2000). The State is under a positive obligation to take all steps necessary to ensure that these rights are guaranteed in practice as well as in theory, including the organisation of the judiciary.

58 Conf Art 23 Statute of the Court of Justice read in conjunction with Art 96.1(c) Rules of Procedure of the Court of Justice with regard to the well-defined role of the European Commission within the mechanics of the preliminary ruling procedure in all its forms, PPA and PPU included.

59 Although in fairness it is certainly not only the so-called 'new' Member States that raise questions in this respect. According to the abovementioned Report of the Committee on Legal Affairs of the European Parliament (n 31), the majority of Belgian and French respondents (87\% and 94\% respectively) considered themselves unfamiliar with the preliminary ruling procedure at that time. Cf p 21 of the Report.

60 Within the European institutions, as well as the Association of the Councils of State and Supreme Administrative Jurisdictions of the European Union.

61 'As a first priority, the working group recommends to raise the level of knowledge of European law of all judges.' Cf Report of the Working Group on the Preliminary Ruling Procedure (n 31) 5. However, one should also keep in mind that this issue had already been mentioned before the Enlargements of 2004 and 2007. Cf Report on the Future of the Judicial System of the European Union, (1999) and the so-called Ole Due Report (n 31).

62 According to the Report of the Committee on Legal Affairs of the European Parliament (n 31), 32\% of the respondents were unfamiliar with the procedure, while $14 \%$ were very familiar. The Report showed the differences between the various Member States. Austrian, Czech and German respondents considered themselves the least unfamiliar with the procedure (12\%, 13\% and 18\% of 'unfamiliar' responses respectively).

63 According to the Report of the Committee on Legal Affairs of the European Parliament (n 31). These are the most recent data available in this field.
} 
Let us come back to the point of departure, ie the role, meaning and functions of the preliminary reference system and the lessons to be learnt in this respect from the Slovak Pension Cases. It is fundamental to keep in mind that the maintenance of the rule of law in European integration can only be successful if it is understood as a common endeavour and joint responsibility of the European Courts in Luxembourg and the national courts. A possible moral of the Slovak Pension Cases experience may therefore be making proper use of the procedural mechanisms offered by the European legal system and entering into a real dialogue.

\subsection{Ultra vires review}

A question that automatically comes to mind when discussing judicial dialogue is that of ultimate authority, in other words: Who has the last say? An extensive discussion of the concept of ultra vires review with respect to acts of organs of the European Union can only be achieved in a framework larger than the one of the present contribution. One point should, however, be mentioned. The CCC repeatedly makes reference to the relevant jurisprudence of the German Federal Constitutional Court (GFCC), which can be traced further back, but which was put forward as early as the Maastricht decision, ${ }^{64}$ stating that legal acts of the Union which exceed the competences outlined in the treaty, as interpreted by the German court will not be legally binding in Germany'. ${ }^{65}$ After the ensuing Lisbon decision that reaffirmed the GFCC's hitherto claims, ${ }^{66}$ the latter took a step backwards in the Honeywell decision. ${ }^{67}$ Further to introducing specific requirements for the use of such powers, the GFCC also strengthened the role of the CJEU in this concept, and thus the mechanism of judicial dialogue, by stating that:

\footnotetext{
64 German Federal Constitutional Court, BVerfGE 89, 155 (1993) judgment of 12 October 1993 in cases 2 BvR 2134/92, 2 BvR 2159/92. For academic appraisal see, inter alia, Steve $\mathrm{J}$ Boom, "The European Union after the Maastricht Decision: Is Germany the "Virginia of Europe"?' (1995) 5 Jean Monnet Working Paper available at <http://centers.law.nyu.edu/ jeanmonnet/archive/papers/95/9505ind.html> accessed 27 December 2013; Carl Otto Lenz, 'Der europäische Grundrechtsstandard in der Rechtsprechung der Europäischen Gerichtshofs', (1993) 20 EuGZ 585; Carl Otto Lenz, 'Der Vertrag von Maastricht nach dem Urteil des Bundesverfassungsgerichts' (1993) 47 NJW 3038-3039; Christian Tomuschat, 'Die Europäische Union unter der Aufsicht des Bundesverfassungsgerichts' (1993) EuGZ 20, 489; JHH Weiler, 'Does Europe Need a Constitution? Reflections on Demos, Telos and the German Maastricht Decision' (1995) 1 ELJ 219-258.

65 Maastricht judgment (n 64). Cf Boom (n 64).

66 German Federal Constitutional Court, Lisbon judgment of 30 June 2009, BVerfG, 2 BvE 2/08. An official English language translation is available at <http://www.bverfg.de/ entscheidungen/es20090630_2bve000208en.html> accessed 27 December 2013.

67 German Federal Constitutional Court, Honeywell judgment of 6 July 2010, 2 BvR 2661/06. An official English language translation is available at <http://www.bverfg.de/ entscheidungen/rs20100706_2bvr266106en.html> accessed 27 December 2013.
} 
Prior to the acceptance of an ultra vires act on the part of the European bodies and institutions, the Court of Justice is therefore to be afforded the opportunity to interpret the Treaties, as well as to rule on the validity and interpretation of the legal acts in question, in the context of preliminary ruling proceedings according to Article 267 TFEU. As long as the Court of Justice did not have an opportunity to rule on the questions of Union law which have arisen, the Federal Constitutional Court may not find any inapplicability of Union law for Germany. ${ }^{68}$

In spite of the fact that the CCC strongly relies on the GFCC when it comes to the establishment of a dogmatic foundation for its competence to exercise an ultra vires review, it does however avoid going down this road to the very (and decisive) end by not making a reference itself before declaring a judgment by the CJEU ultra vires. ${ }^{69}$ As is well known, the $\mathrm{CCC}$ is not the only national court to reject the CJEU's assertion of hierarchical authority over national courts in questions related to European Union law. ${ }^{70}$ The CCC's judgment is, however, still an outstanding one, as for the first time the constitutional court of a Member State did not only claim to possess the competence of ultra vires review, but actually exercised it. Given the extraordinary character of this act, one would have expected to find a deliberately well-drafted and meticulously well-argued passage in the judgment of the $\mathrm{CCC}$, underpinning such competence. However, in this respect the CCC merely states

that there were excesses on the part of a European Union body ... a situation occurred in which an act by a European body exceeded the powers that the Czech Republic transferred to the European Union under Art 10a of the Constitution; this exceeded the scope of the transferred powers and was ultra vires. ${ }^{71}$

Surprisingly, the CCC did not therefore provide a valid and comprehensible foundation for the competence it exercises.

\footnotetext{
68 Honeywell (n 67) para 60.

69 The fact that the CCC has actually never lodged a reference for a preliminary ruling has already been pointed out above.

70 See, inter alia, the decisions of the German Federal Constitutional Court in the Solange I judgment of 19 May 1976, BVerfGE 37, 271; Solange II judgment of 22 October 1986, 2 BvR 197/83; Maastricht (n 64); Lisbon (n 66); and other Constitutional Courts on the Lisbon Treaty: French Constitutional Council, Decision of 20 December 2007, 2007-560 DC; Latvian Constitutional Court - judgment of 7 April 2009, 2008-35-01; Polish Constitutional Court - Treaty of Lisbon judgment of 16 November 2011, K32/09; Czech Constitutional Court Lisbon I judgment of 26 November 2008, Pl. ÚS 19/08 and Lisbon II judgment 3 November 2009, PL. ÚS 29/09; as well as previous decisions of the Czech Constitutional Court, such as the European Arrest Warrant judgment of 3 May 2006, Pl. ÚS 66/04; and similar decisions of the Polish Constitutional Court in the Accession Treaty judgment of 11 May 2005 K18/04, as well as the most recent development in the decision of 16 November 2011, SK 45/09.

71 Czech Constitutional Court, Slovak Pension XVII judgment (n 26) Part VII.
} 


\section{Conclusions}

After the second preliminary reference from the SAC, a final assessment of the Slovak Pension Cases was for a while not possible. It can be stated, however, that the spectacular effect of the CCC's ultra vires judgment quickly passed. With the benefit of hindsight, this can be confirmed by the fact that no other national court so far has drawn inspiration from the judgment of the CCC. ${ }^{72}$ At least for the time being, the overall authority of the CJEU has not suffered a serious blow from it. On the contrary, the judgment has received serious criticism in academic circles, further weakening the already shaky position the CCC had manoeuvred itself into.

What happened was only to be expected in a non-hierarchical, multi-level court system, where upper level courts are not empowered to reverse the decisions of lower level courts. A lower level court expressed its strong disagreement and insisted on its own interpretation of the law. The European legal order has seen similar cases before (even though they may not have been as pronounced as the Slovak Pension Cases) and will certainly experience further ones. In this sense, relations between national courts and the CJEU may be going through a period of normalisation, and what once was considered spectacular may now be termed banal. In other words: The Slovak Pension Cases developed from judicial drama to judicial farce.

However, what is certainly of great importance is that the courts involved return to an overall spirit of co-operation rather than confrontation, and return to a complementary rather than competitive approach.

Last but not least, if the lack of familiarity with the procedures of European judicial dialogue strikingly displayed by the cases at hand lead to an improvement in this point and proper use of this mechanism, something bad may in the end even turn out to be something good.

$\overline{72}$ To the best of the authors' knowledge. 